\title{
High Nature Value Grasslands from Arrhenatherion Alliance Identified in Mureş County
}

\author{
Silvia OROIAN ${ }^{1}$, Mihaela SĂMĂRGHIȚAN ${ }^{2}$, Mariana HIRIȚIU ${ }^{1}$, Sanda COŞARCA ${ }^{1}$, Corneliu \\ TANASE $^{1 *}$ \\ ${ }^{1}$ University of Medicine and Pharmacy, Faculty of Pharmacy, 38 Gh. Marinescu Street, RO-540139 \\ Târgu Mureş \\ ${ }^{2}$ Mureș County Museum, Department of Natural Sciences, 24 Horea Street, RO-540036 Târgu Mureș, \\ Romania \\ *corresponding author: tanase.corneliu@yahoo.com
}

Bulletin UASVM series Agriculture 73(2)/2016

Print ISSN 1843-5246; Electronic ISSN 1843-5386

DOI 10.15835/buasvmcn-agr: 12419

\begin{abstract}
Arrhenatherion alliance meadows are recognized to be among the best pastures in our country due to high productivity and good nutrition value. The research was conducted in several areas of Mures County. The studied grasslands were classified into two types of Natura 2000 habitats: 6510 Lowland hay meadows (Alopecurus pratensis, Sanguisorba officinalis) and 6520 Mountain hay meadows. The identified phytocoenosis belong to two plant associations: Arrhenatheretum elatioris Br.-Bl. Ex Scherrer 1925 and Poo Trisetetum flavescentis (Knapp 1951) Oberd. 1957. The analysis of data collected in the field reveals that the current state of conservation of the two types of habitat is good and very good. Habitats in a good and very good state of preservation is distinguish by a great floristic composition: approx. 100-150 cormophyte species with good and very good forage value. As habitats are more susceptible to the management applied and any changes to land use can affect habitat quality (eg abandoning mowing and turning the land into pasture), the ecological functions of this habitat will be satisfied as long as they are mowed after Poaceae species matured.
\end{abstract}

Keywords: grasslands, habitats, Mureș County, Transylvania.

\section{INTRODUCTION}

High natural value farmland comprises those areas in Europe where agriculture is a major (usually dominant) land use and where that agriculture supports or is associated with either a high species or habitat diversity or the presence of species of European conservation concern or both. (Andersen et al. 2003)

A precise delimitation of High Nature Value (HNV) grasslands is particularly important, because it leads to a more effective framework of measures for the maintenance of habitats and species that depend on agricultural management (Halada et al. 2011).

The reaserch was conducted in several localities in Mures county, this research identified grasslands rich in species which produce good and very good quality hay. These grasslands were also clasified in varying types of Natura 2000 habitats

Establishing and implementing stronger measures for maintenance of habitats and species dependent on agricultural management by providing accurate knowledge of grasslands with a high natural value in the Mureș county, their location and their floristic composition.

\section{MATERIALS AND METHODS}

To identify, describe and clasify the plant associations from Arrhenatherion Koch 1926 alliance we used the system of Coldea (2012). To establish the Natura 2000 habitats that these phytocoenosis belong the researchers used $A$ 
handbook for interpreting NATURA 2000 habitats in Romania (Gafta and Mountford, 2008) and Habitats in Romania, (Doniță et al., 2005). In order to describe and analize the plant associations, some phytosociological indexes (Cristea et al., 2004) were taken into consideration (Constance and Frequency). Using these resources a quantitative estimation of the plant species was made, including those species having indicators of high natural value grasslands. Statistical analyse was also carried out.

The phytosociological index used, and their values are:

Constancy $(\mathrm{K})$ phytocoenotic index

I - the species is found in less than $20 \%$ of the surveys

$$
\begin{aligned}
& \text { II - 21-40\% } \\
& \text { III - 41-60\% } \\
& \text { IV - 61-80\% } \\
& \text { V- } 81-100 \%
\end{aligned}
$$

Frequency: quantitative phyto-poplulational index

$$
\mathrm{F}=\frac{\mathrm{n} \times 100}{\mathrm{~N}}
$$

$\mathrm{n}=$ the number of areas in which the certain species is present

$\mathrm{N}=$ total number of surveys

The parameters used to determine the conservation status of habitats were: the area of natural spread, the area of the habitat, the structure and specific functionality of the habitat, the future prospect associated with it. (Directiva Habitate, 1992)

\section{RESULTS AND DISCUSSION}

The studied phytocoenosis were framed in two plant associations: Arrhenatheretum elatioris Br.-Bl. ex Scherrer 1925, belonging to the habitat 6510 Low land meadows (Alopecurus pratensis,

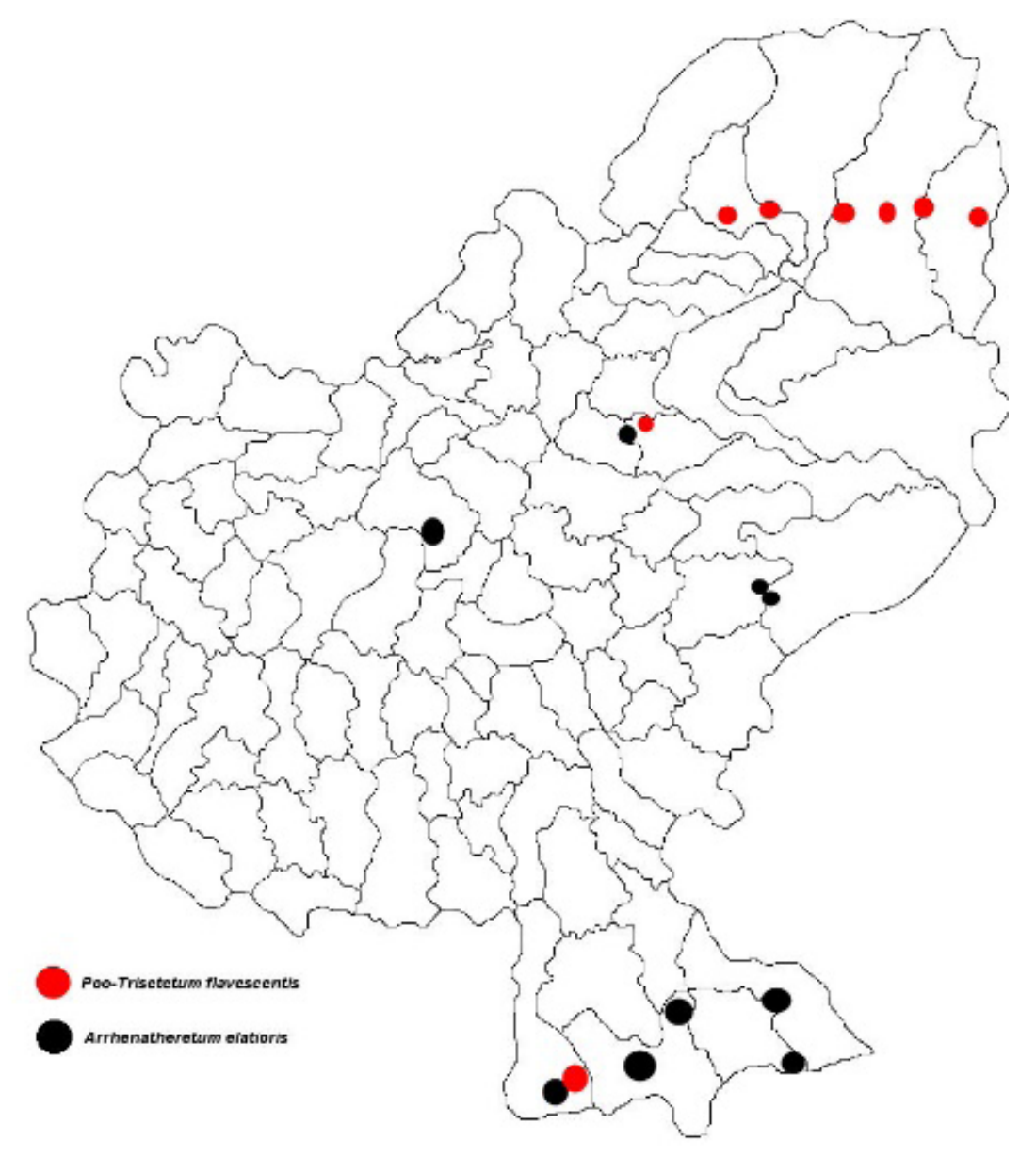

Fig. 1. The spread of studied associations in Mures county 
Sanguisorba officinalis) and Poo-Trisetetum flavescentis (Knapp 1951) Oberd. 1957 included in 6520 Mountain hay meadows Natura 2000 habitat.

With 201 taxa being identified in the 21 phytosociological surveys a wealth of species exhibiting a rich floristic composition of phytocoenosis. These plants included many medicinal and fodder varities a rich floristic composition of phytocoenoses was observed. These meadows are considered to be among the best pastures in the country, with a very high productivity and very good nutritional value.

The phytocoenosis of Arrhenatheretum elatioris Br-Bl. ex Scherrer 1925 association were identify in the vicinity of several localities in Mures county: Șilea Nirajului dl. Becheci, Stejăreni, Mihai Viteazu, Saschiz, Archita, Apold, Beica de Sus, Herghelia (Fig. 1).

The Poo-Trisetetum flavescentis (Knapp 1951) Oberd. 1957 association was encountred to: Androneasa, Neagra, Ciobotani, Stânceni-
Mermezeu; Răstolița, Bistra Mureșului, Beica de Sus and Archita (Fig. 1).

Syntaxonomical interpretation of these associations (Coldea, 2012) shows that they belong to Molinio-Arrhenatheretea class as below:

Cls. Molinio-Arrhenatheretea R.Tx.1937 em.R.Tx.1970

Ord. Arrhenatheretalia

All. Arrhenatherion

Arrhenatheretum elatioris Br.-Bl. Ex Scherrer

Poo-Trisetetum flavescentis (Knapp 1951) Oberd. 1957

\section{Characterization of the plant associations}

Ass. Arrhenatheretum elatioris Br.-Bl. Ex Scherrer

Regions of hills and mountains at altitudes

Tab. 1. Characteristic species for the coenotaxa that subordinated association Arrhenatheretum elatioris Br.-Bl. Ex Scherrer

\begin{tabular}{|c|c|c|c|c|c|}
\hline Arrenatherion & $\mathbf{K}$ & & $\mathbf{K}$ & & $\mathbf{K}$ \\
\hline $\begin{array}{c}\text { Arrhenatherum } \\
\text { elatius }\end{array}$ & $\mathrm{V}$ & Daucus carota & III & Rhinanthus angustifolius & III \\
\hline Campanula patula & $\mathrm{V}$ & $\begin{array}{c}\text { Tragopogon pratensis ssp. } \\
\text { orientalis }\end{array}$ & III & Stellaria graminea & III \\
\hline Crepis biennis & II & Trifolium hybridum & III & Holcus lanatus & II \\
\hline Centaurea nigrescens & $\mathrm{I}$ & Carum carvi & II & Melilotus officinalis & II \\
\hline Cynosurion & & Rorippa pyrenaica & II & Eryngium planum & II \\
\hline Cynosurus cristatus & III & Veronica chamaedrys & II & Euphrasia rostkoviana & II \\
\hline Leontodon autumnalis & II & Vicia sepium & II & Festuca pratensis & II \\
\hline Phleum pratense & II & Anthriscus sylvestris & $\mathrm{I}$ & Festuca rubra & II \\
\hline Trifolium repens & II & Carex flacca & I & Phleum pratense & II \\
\hline Arrhenatheretalia & & Heracleum sphondylium & I & Trisetum flavescens & II \\
\hline Briza media & $\mathrm{V}$ & Trifolium dubium & $\mathrm{I}$ & Alopecurus pratensis & $\mathrm{I}$ \\
\hline Campanula patula & $\mathrm{V}$ & $\begin{array}{c}\text { Molinio- } \\
\text { Arrhenatheretea }\end{array}$ & & Galium mollugo & I \\
\hline Dactylis glomerata & $\mathrm{V}$ & Anthoxanthum odoratum & IV & Gladiolus imbricatus & $\mathrm{I}$ \\
\hline Knautia arvensis & $\mathrm{V}$ & Prunella vulgaris & IV & Gymnadenia conopsea & $\mathrm{I}$ \\
\hline $\begin{array}{l}\text { Leucanthemum } \\
\text { vulgare }\end{array}$ & $\mathrm{V}$ & Cerastium holosteoides & III & Lathyrus pratensis & I \\
\hline Achillea millefolium & $\mathrm{V}$ & Trifolium pratense & III & Poa trivialis & $\mathrm{I}$ \\
\hline Lotus corniculatus & $\mathrm{V}$ & Plantago lanceolata & III & Silene vulgaris & $\mathrm{I}$ \\
\hline Agrostis capillaris & IV & Ranunculus acris & III & Vicia cracca & I \\
\hline Plantago media & III & Rumex acetosa & III & & \\
\hline
\end{tabular}


Tab. 2. Species of Arrhenatheretum elatioris Br.-Bl. Ex Scherrer association with forage value: Very good $(\mathrm{VG})$, Good (G) and Average (A)

\begin{tabular}{cccccc}
\hline Species & FV & Species & FV & Species & FV \\
\hline Arrhenatherum elatius & VG & Agrostis capillaris & G & Briza media & A \\
\hline Dactylis glomerata & VG & Cynosurus cristatus & G & Anthyllis vulneraria & A \\
\hline Festuca pratensis & VG & Festuca rubra & G & Elymus repens & A \\
\hline Medicago falcata & VG & Poa trivialis & G & Festuca rupicola & A \\
\hline Medicago sativa & VG & Trisetum flavescens & G & Lathyrus pratensis & A \\
\hline Onobrychis viciifolia & VG & Trifolium hybridum & G & Melilotus officinalis & A \\
\hline Phleum pratense & VG & Medicago lupulina & G & Trifolium montanum & A \\
\hline Trifolium pratense & VG & Lotus corniculatus & G & & \\
\hline Trifolium repens & VG & Trifolium alpestre & G & \\
\hline & Trifolium campestre & G & \\
\hline & Vicia cracca & G & \\
\hline
\end{tabular}

between 350-675 m provide an ideal environment for phytocoenosis dominated by the tall oatgrass. These semi-natural grasslands, maintained by mowing or grazing, prefer deep soils, brown luvic and brown mountain soils, fertile, slightly acidic, a very balanced level of moisture, with rainfall between $600 \mathrm{~mm}$ and $800 \mathrm{~mm} /$ year in climates with average annual temperature between $6.5^{\circ} \mathrm{C}$ and $9^{\circ} \mathrm{C}$. Floristic composition reveals great wealth, 169 taxa being identified in the 11 phytosociologic surveys.

The association description reveal the characteristic species of coenotaxa that subordinate the association (Tab. 1). These species are quantitative dominant. Phytosociological table reveals that the indicative value of a species grows in direct proportion to its abundance and dominance (Cristea et al., 2004).

The characteristic and dominant species for association are: Arrhenatherum elatius, Trisetum flavescens, Crepis biennis, Knautia arvensis, Tragopogon pratensis, Daucus carota, Leucanthemum vulgare, Campanula patula etc. We mention that in this association's composition were identified numerous medicinal and forage plant species (Tab. 2).

The productivity of green matter per hectare is average (15000-25000 kg/ha) and give a good quality hay (Marușca et al., 2010).

We note the presence in the composition of this association of species belonging to different sozological categories that are listed in National Red Lists (Boșcaiu et al., 1994; Oltean et al., 1994):
Dictamnus albus L., Gymnadenia conopsea (L.) R. Br. and Salvia transsilvanica (Schur ex Griseb. et Schenk) Schur. In the association composition stands also the presence of invasive species Erigeron annuus, which should be monitored to prevent its extension to the detriment of native species.

Ass. Poo-Trisetetum flavescentis (Knapp 1951) Oberd. 1957

Southeast Carpathian meadows of Trisetum flavescentis prefer less inclined slopes with northern or northeastern orientation at altitudes of $650-800 \mathrm{~m}$ in climate with average annual temperature of $6^{\circ} \mathrm{C}$ and $7^{\circ} \mathrm{C}$ and rainfall between $700 \mathrm{~mm}$ and $800 \mathrm{~mm} /$ year. They grow on Eutricambosoils which are rich in nutrients and moderately moist, neutral to slightly acidic.

The floristical composition reveals the presence of edifying and characteristic species: Trisetum flavescens, Cerastium holosteoides, Anthoxanthum odoratum, Briza media, Dactylis glomerata, Festuca pratensis. Other important species are: Agrostis capillaris, Poa pratensis, Arrhenatherum elatius, Trifolium pratensis, Ononis arvensis, Lotus corniculatus, Rumex acetosa, Polygonum bistorta, Holcus lanatus, Leucanthemum vulgare, Daucus carota, Achillea millefolium, Silene vulgaris, Dianthus carthusianorum.

Regarding the affiliation to different coenotic groups one can notice a high proportion of species belonging to Arrhenatherion 
Tab. 3. Characteristic species for the coenotaxa that subordinated association Poo-Trisetetum flavescentis (Knapp, 1951) Oberd. 1957

\begin{tabular}{cccccc}
\hline Arrenatherion & K & & K & & K \\
\hline Trisetum flavescens & V & Briza media & III & Prunella vulgaris & IV \\
\hline Arrhenatherum elatior & V & Knautia arvensis & III & Stellaria graminea & IV \\
\hline Crepis biennis & III & Rhinanthus rumelicus & II & Plantago lanceolata & IV \\
\hline Campanula patula & II & Carum carvi & III & Agrostis capillaris & III \\
\hline Centaurea phrygia & II & Daucus carota & II & Festuca pratensis & III \\
\hline Centaurea nigrescens & I & Leontodon hispidus & II & Holcus lanatus & III \\
\hline Geranium pratense & I & Galium mollugo & II & Trifolium pratense & III \\
\hline Cynosurion & & Lotus corniculatus & II & Vicia cracca & III \\
\hline Trifolium repens & IV & Tragopogon pratensis ssp. & II & Ranunculus acris & III \\
\hline Cynosurus cristatus & IV & Veronica chamaedrys & II & Cerastium holosteoides & II \\
\hline Phleum pratense & II & Ajuga reptans & II & Euphrasia rostkoviana & II \\
\hline Veronica serpyllifolia & 1 & Plantago media & II & Lathyrus pratensis & II \\
\hline Polygono-Trisetion & & Taraxacum officinale & I & Rumex acetosa & II \\
\hline Centaurea pseudophrygia & I & Trifolium hybridum & I & Viola tricolor & II \\
\hline Polygonum bistorta & I & Campanula glomerata & I & Festuca rubra & I \\
\hline Trollius europaeus & 1 & Eryngium planum & I & Centaurea jacea & I \\
\hline Arrhenatheretalia & & Rorippa pyrenaica & I & Pastinaca sativa & I \\
\hline Poa pratensis & V & Trifolium dubium & I & Poa trivialis & I \\
\hline Dactylis glomerata & V & Vicia sepium & I & Rhinanthus angustifolius & I \\
\hline Achillea millefolium & IV & Molinio-Arrhenatheretea & & Alopecurus pratensis & I \\
\hline Leucanthemum vulgare & IV & Anthoxanthum odoratum & V & Danthonia decumbens & I \\
\hline
\end{tabular}

alliance, Arrhenatheretalia order and MolinioArrhenatheretea class (Tab. 3).

In this association can be noticed also rare, endangered, species listed in National Red Lists:
Epipactis helleborine (L.) Crantz, Gymnadenia conopsea (L.) R. Br., Trollius europaeus L. Due the proximity of human settlements and crops the ruderalisation process is favorised. Also, be aware

Tab. 4. Species of Poo -Trisetetum flavescentis (Knapp 1951) Oberd. 1957 association with forage value: Very good (VG), Good (G) and Average (A)

\begin{tabular}{cccccc}
\hline Species & FV & Species & FV & Species & FV \\
\hline Arrhenatherum elatius & VG & Agrostis capillaris & G & Anthyllis vulneraria & A \\
\hline Dactylis glomerata & VG & Alopecurus pratensis & G & Briza media & A \\
\hline Festuca pratensis & VG & Cynosurus cristatus & G & Lathyrus pratensis & A \\
\hline Medicago falcata & VG & Festuca rubra & G & Melilotus officinalis & A \\
\hline Onobrychis viciifolia & VG & Lotus corniculatus & G & Trifolium montanum & A \\
\hline Phleum pratense & VG & Medicago lupulina & G & & \\
\hline Poa pratensis & VG & Poa trivialis & G & \\
\hline Trifolium pratense & VG & Trifolium alpestre & G & \\
\hline Trifolium repens & VG & Trifolium campestre & G & \\
\hline & & Trifolium hybridum & G & & \\
\hline & & Trisetum flavescens & G & & \\
\hline
\end{tabular}


Tab.5. Evaluation matrix for conservation status of habitats on basis of occupied area, structure and specific functions of the habitat

\begin{tabular}{ccc}
\hline Habitat type & \multicolumn{2}{c}{ Conservation status } \\
\cline { 2 - 3 } $\begin{array}{c}\text { 6510 Lowland hay meadows (Alopecurus pratensis, Sanguisorba } \\
\text { officinalis) }\end{array}$ & $\begin{array}{c}\text { in terms of structure } \\
\text { and specific functions } \\
\text { of the habitat }\end{array}$ \\
\hline $\mathbf{6 5 2 0}$ Mountain hay meadows (Fig. 2) & F & U-I \\
\hline
\end{tabular}

of the invasive species Erigeron annuus which, while not spread on large territories, must be kept under control to prevent its development to the detriment of native species.

The productivity of green matter per hectare is average $(15000 \mathrm{~kg} / \mathrm{ha})$ and give a good quality hay (Marușca et al., 2010). The studied phytocoenosis belong to two types of Natura 2000 habitats: $\mathbf{6 5 1 0}$ Lowland hay meadows (Alopecurus pratensis, Sanguisorba officinalis) and $\mathbf{6 5 2 0}$ Mountain hay meadows (Fig. 2).

Analysing the field data it can be appreciated that the present state of conservation status of 6510 habitat is favorable; in over $50 \%$ of surveys recorded habitat conservation status is good and very good (Tab. 4).

Following the field observations it was found that both habitats are in an unfavorable-inadequate conservation status (Tab. 5). The habitats have a current trend of occupied area stable and the specific structure and functions necessary for the further preservation, including its typical species not in good conservation condition. Many areas

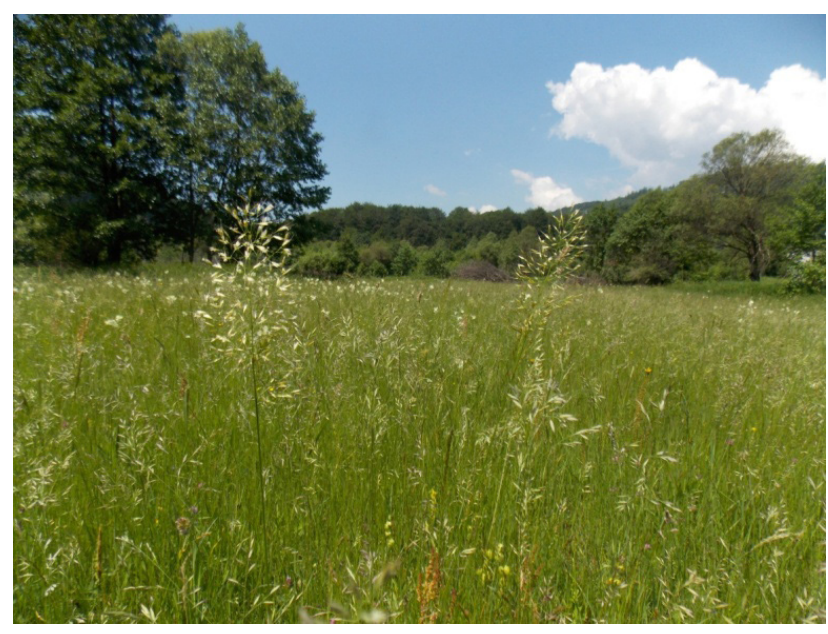

Fig. 2. 6520 habitat, grasslands with Trisetum flavescensand Poa pratensis (foto M. Sămărghițan) occupied of the dentified habitats are damaged in terms of their structure and functions. The probability of maintaining them in the foreseeable future is high in terms of applying appropriate management measures.

\section{Management measures proposed:}

- Keeping mowing as the primary activity of management of these meadows; rational grazing, using species and number of animals allowed, depending on the carrying capacity of the pasture.

- Restrict the use of fertilizers, particularly those chemical that can induce sequence to another type of habitat.

- Control of invasive species, including woody ones: this prevent expansion of alien invasive species or the wood by manual or mechanical removal thereof. It is recommended especially for abandoned or undergrazed grasslands.

- Arson solids control. This measure will apply only with the approval of the environmental authorities and only in special cases, as a last resort and under strict control.

\section{CONCLUSION}

- The grasslands edified by Arrhenatherum elatior and Trisetum flavescens were studied in different places in Mures County;

- The results identified two types of habitats: 6510 and 6520 ;

- Associations reported in the two habitat types are Arrhenatheretum elatioris Br.-Bl. Ex Scherrer and Poo-Trisetetum flavescentis (Knapp 1951) Oberd. 1957

- In the floristic composition of phytocoenoses there were identified rare or endemic species: Dictamnus albus L., Epipactis helleborine (L.) Crantz, Gymnadenia conopsea (L.) R. Br., Salvia 
transsilvanica (Schur ex Griseb. et Schenk) Schur, R. Br. and Trollius europaeus L.

- The conservation status of habitats is unfavorable- inadequate.

- The probability of maintaining habitats in the foreseeable future is great in terms of applying appropriate management measures.

\section{REFERENCES}

1. Andersen E, Baldock D, Bennet H, Beaufoy G, Bignal E, Brower F, Elbersen B, Eiden G, Godeschalk F, Jones G, McCracken DI, Nieuwenhuizen W, van Eupen M, Hennekes S, Zervas G (2003). Developing a high nature value indicator. Report for the European Environment Agency, Report for the European Environment Agency, Copenhagen.

2. Boşcaiu N, Coldea Gh, Horeanu Cl (1994). Lista roşie a plantelor vasculare dispărute, periclitate, vulnerabile şi rare din flora României. Ocrot.Nat. Med.Înconj., 38 (1):4556.

3. Coldea G (2012). Les associations végétales de Roumanie, tom 2. Les associations herbacées anthropogène. Presses Universitaires de Cluj, Cluj-Napoca.
4. Cristea V, Gafta D, Pedrotti F (2004). Fitosociologie. Edit. Presa Universitară Clujeană, Cluj-Napoca.

5. Doniță N, Popescu A, Paucă-Comănescu M, Mihăilescu S, Biriş IA (2005). Habitate din România. Edit. Tehnică Silvică București.

6. Gafta D, Mountford 0 (coord.) (2008). Manual de interpretare a habitatelor Natura 2000 din România. Ed. Risoprint, Cluj-Napoca.

7. Halada L, Evans D, Romão C, Petersen JE (2011). Which habitats of European importance depend on agricultural practices? Biodiversity and Conservation. 20:2365-2378.

8. Maruşca T (coord.), Mocanu V, Cardaşol V, Hermenean I (2010). Ghid de producere ecologică a furajelor de pajiști montane. Ed. Universității "Transilvania" Braşov. 8-25.

9. Oltean M, Negrean G, Popescu A, Roman N, Dihoru G, Sanda V, Mihăilescu S (1994). Listă roşie a plantelor superioare din România, Studii, sinteze, documentații de ecologie, Acad. Română, Instit. de Biologie, București. 1:1-52.

10. *** Council Directive 92/43/EEC of 21 May 1992 on the conservation of natural habitats and of wild fauna and flora 